attention of the educational section. Mr. Fletcher's own paper, which followed, dealt with the development of technical education in a new country, and suggested that many of the methods which had been successful in Ireland in the way of creating public interest and of eliciting the ccoperation of the locality might well be adopted in South Africa. Nor should the Administration be deterred from making a start with technical education at any centre by reports as to the apathy of the residents; Irish experience would seem to show that a supply of good instruction would always produce an increasing demand for $\mathrm{jt}$.

The very important question of agricultural education was treated at Johannesburg by Mr. F. B. Smith, the Director of Agriculture in the Transvaal, and by Mr. A. D. Hall at Cape Town. Mr. Smith showed how efficiently an intelligence department had already been organised in the matter of agriculture in the Transvaal, where the farmer had at his call a service for investigation and advice which could not be rivalled in any other British country. An enormous amount of work had now been done on such matters as the introduction of improved crops, the eradication of stock diseases, \&c., and the Afrikander farmer was beginning to rely upon the help of the department. Mr. Smith further outlined the nature of the course it was proposed eventually to establish in the Transvaal in connection with the future university. Mr. Hall was disposed to think that questions of economy would necessitate the colonies concentrating their efforts chiefly upon their expert staff for investigation and work among the current generation of farmers, and that there was not the same call for another staff to give instruction in the higher branches of agricultural science. The type of instruction for which the most pressing demand existed was a practical training in more improved methods of farming, and this could well be developed in connection with the experimental farms that had already been instituted in various parts of the country. It seemed as yet hardly worth while to create an elaborate teaching institution to produce the small number of experts and Government officers whom the country would require yearly, since suitable men could be picked out during the earlier practical courses of instruction and sent home to complete their scientifio training.

One question, which recurred constantly during the tour, both in section meetings and in conversation, was that of native education, a thorny subject interwoven with many prejudices, both racial and religious. The general feeling among colonials is almost wholly opposed to education of what may not unfairly be called the ordinary missionary type, which seeks to teach the native to read and write English. Many large employers of labour refuse to engage any native acquainted with English, and other experienced men declare that the only effect of such a bookish training as has been given in the past is to make the native parasitic, either upon the white community or his more primitive fellows. But education by means of handicrafts, and proceeding entirely in the natives' own language, meets with general approval, both as supplying a much desiderated discipline and making the native more efficient economically, and also as likely to prove a sound method of eventually leading the native on to a higher plane of civilisation. This is essentially a matter on which the visitor can only speak with diffidence; indeed, it is claimed that many of the difficulties have arisen from the ill-considered, though well meaning, action of people at home.

The papers of more general interest included a discourse by Dr. J. H. Murray on "the world of words," in which he discussed, with appropriate illustrations from the English language, the various types of words and the manner in which they originated. Dr. Brill, rector of the Grey College at Bloemfontein, again submitted a paper of great interest on the origin of the "Tael," the form of Dutch commonly spoken throughout South Africa. The Tael he holds to be a pure Dutch, "clipped," however, by the removal of practically all inflexions, genders, and irregular forms. What little foreign element exists in the language he attributes to early intercourse with the East, and regards it in the main as of Malayo-Portuguese origin. The members of the British Association who were interested in education had many opportunities of secing the schools in the centres they visited, and also of intercourse with the teachers at work in them. The raw material with which the latter have to deal may not as yet have imbibed any great keenness for learning, but the general attitude of the citizens of the country towards education, as indicated, for example, in such matters as school buildings (often in the smaller towns of Cape Colony the most notable public building was the school), shows a life and determination which will not be long before bearing fruit.

\section{THE SCOTTISH NATIONAL ANTARCTIC} EXPEDITION.

A SLMMARY of some of the preliminary scientific results of the Scottish National Antarctic Expedition appeared in the August number of the Scottish Geographical Magazine, and this has now been issued in the form of a corrected reprint, from the office of the expedition in Edinburgh. The pamphlet contains an introduction by $\mathrm{Mr}$. W. S. Bruce, the leader of the expedition, a paper

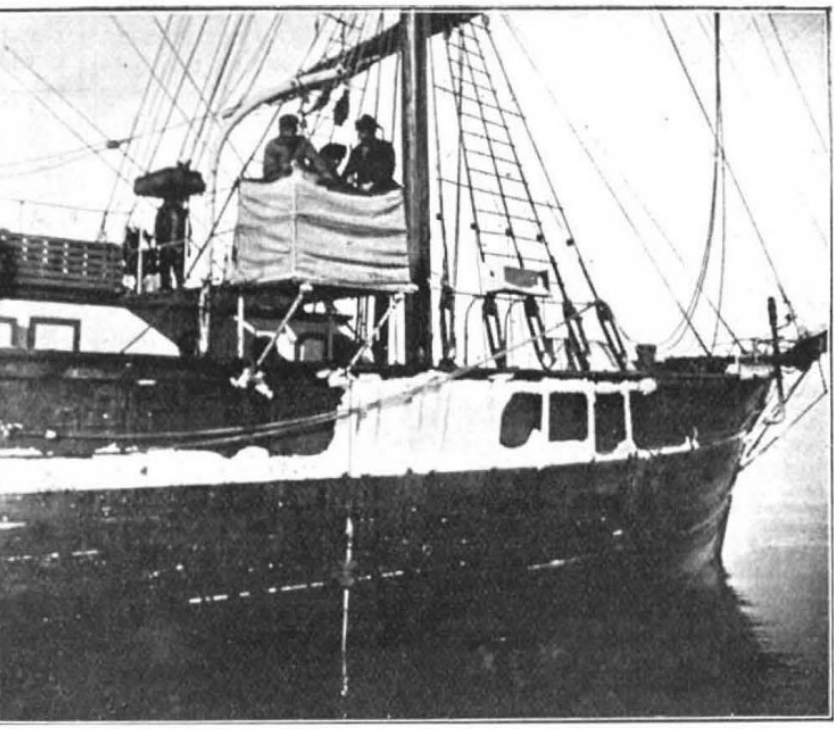

IG. 1. - Scotia sounding in supposed Ross Deep $68^{\circ} 32$ S., $12^{\circ} 49^{\prime}$ W, on March 23, I904.

on the bathymetrical survey of the South Atlantic Ocean and Weddell Sea, also by Mr: Bruce, and short papers on the deep-sea deposits, by Dr. Harvey Pirie, on the meteorology of the expedition, by Mr. Mossman, and on Diega Alvarez, or Gough Island, by Mr. Rudmose Brown. An account of part of the work of the expedition has already appeared in these columns (Nature, March 2).

The most important facts brought to light in the course of the sounding and exploring work are those connected with the discovery of Coats Land, and the final removal from the map of the "Ross deep," in which the Erebus and Terror reported 4000 fathoms no bottom. The supposed coast-line of the Antarctic continent south-east of the Weddell Sea has hitherto been placed in about $80^{\circ} \mathrm{S}$. lat., probably because of the belief, to which certain temperature observations seemed to give support, that Ross's sounding was really correct. The Scotia discovered Coats Land in $72^{\circ} 25^{\prime} \mathrm{S}$., $17^{\circ} 27^{\prime}$ W., and skirted the coast for 150 miles. Within 2 miles of the assigned position of Ross's sounding ( $68^{\circ} 32^{\prime}$ S., $12^{\circ} 49^{\prime}$ W.) the Scotia touched bottom in 2660 fathoms, and the sounder brought up a large sample of blue mud. "Thus," as Mr. 
Bruce puts it, " after more than sixty years of doubt, Ross Deep was removed from the map, and all the bathymetrical maps based upon this sounding were no longer of any practical use. It is interesting to contrast the methods of sounding employed on the two occasions by

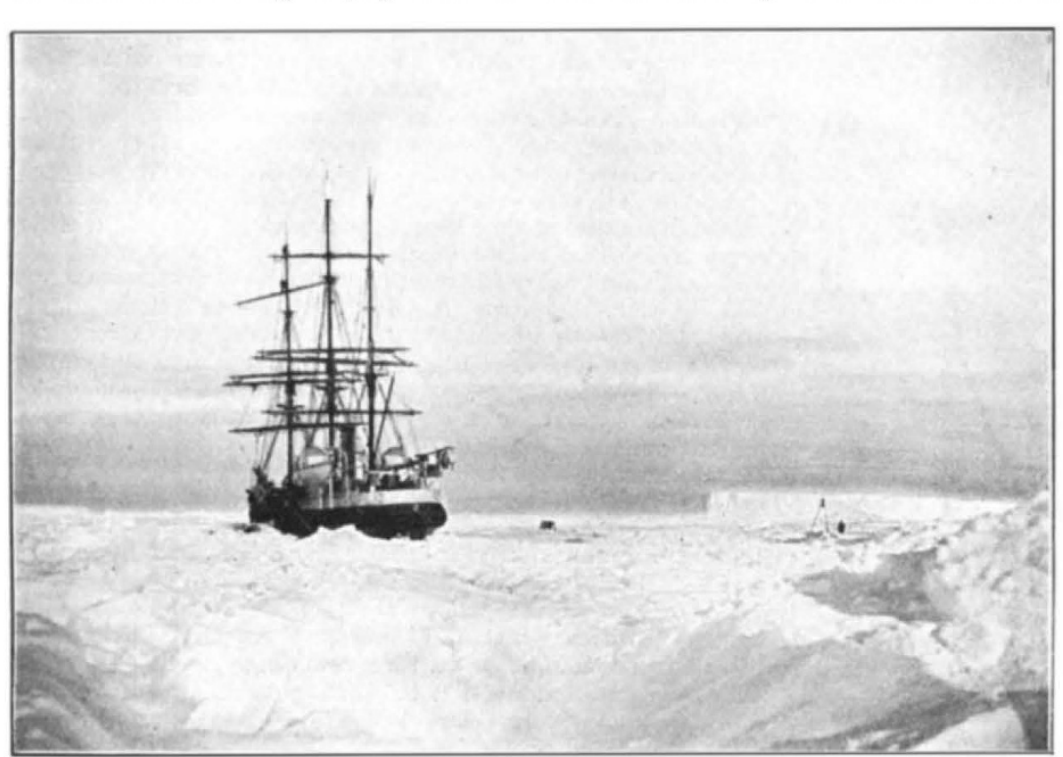

FIG. 2.-Scotia teset in heavy ice in $74^{\circ} \mathrm{x}^{\prime} \mathrm{S}$. off Coats Land. The shearlegs show the position of the baited trap in $76 \mathrm{I}$ fathoms.

comparing Mr. Bruce's photographs, which we reproduce, with the illustration given in Ross's book. Another discovery of great importance is that of a ridge showing a continuation of the "South Atlantic rise" a thousand

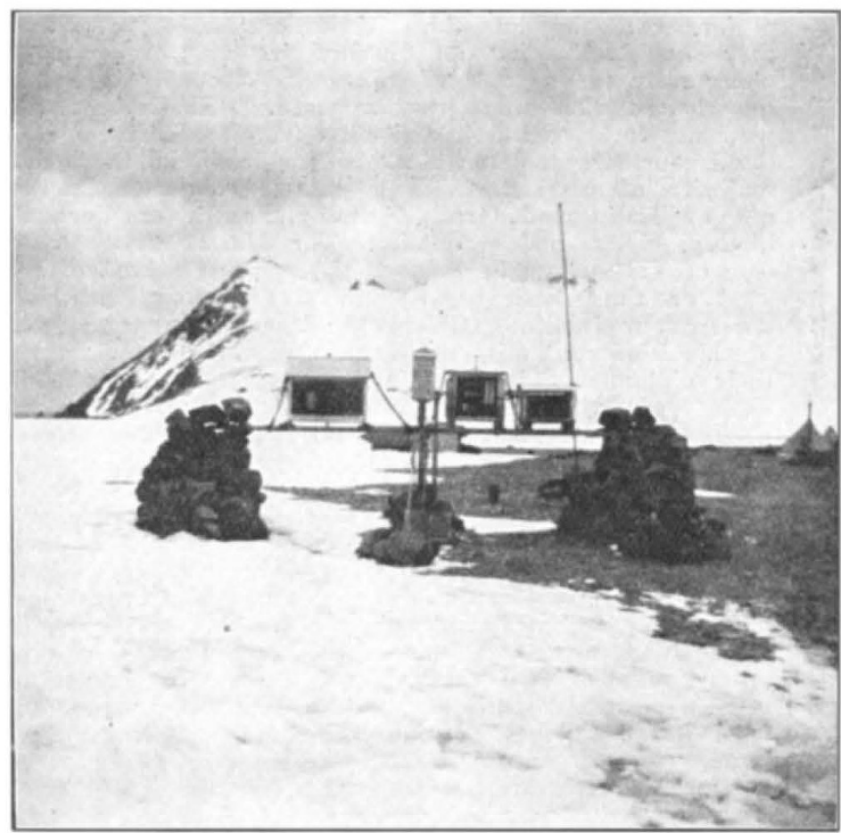

FiG. 3.- Mettorological Instrumeists at Scoitia Bay.

miles further south than it was previously known to exist. There is thus a ridge " extending in a curve from Madagascar to Bouvet Island, and from Bouvet Island to the Sandwich Group, whence there is a forked connection through the South Orkneys to Graham's Land, and No. I 880, VOL. 73] and October 5 . land. through South Georgia to the Falkland Islands and South American continent." .. " Antarctica, South America, and Madagascar, become connected with one another in a most direct manner by this "rise." Basing his arguments on these discoveries, Mr. Bruce strongly opposes Sir Clements Markham's theory, set forth in his recent address to the Royal Geographical Society, that the Antarctic area consists of two land masses of unequal size, Victoria Land and Edward VII. Land, separated by a great barrier of ice, and of two seas extending far to the spouth, the Ross Sea and the Weddell Sea.

The papers by Dr. Harvey Pirie and Mr. Mossman contain many points of great interest, although in the nature of things the material collected requires further elaboration, and comparison with that of the other expeditions, before its full value becomes apparent. Dr. Harvey Pirie's observations give much additional information bearing on the variations in the relative amounts of diatoms in the surface waters and in the deposits, and the remarkable differences in the metecrological values for 1903 and 1904 enable Mr. Mossman to draw many important conclusions as to the factors controlling the climate. $\mathrm{Mr}$. Rudmose Brown gives an interesting account of an island which has, curiously enough, remained unexplored until now, although it lies almost on the track of sailing-ships outward bound via the Cape of Good Hope.

\section{THE PERCY SLADEN EXPEDITION IN \\ H.M.S. SEALARK.}

I HAVE just received the accompanying communication from $\mathrm{Mr}$. Stanley Gardiner, bringing the account of his expedition to September 12, the date of his letter. The letter is written from Coetivey. I may remind readers of Nature that his former communications appeared in the issues of August 10 A. Seduwick.

Zoological I.aboratory, Cambridge, October 23.

Since my last letter Cooper and I have had a tour round the reefs of Mauritius, and have for the last three weeks been working between the latter island and the Seychelles Group. The Mauritius reefs vary from fringing to barrier, the best example of the latter being at Grand Port, where it is four miles from the land. It has there a few small islets of somewhat metamorphosed coral-rock, varying up to 40 fect high. At first it seemed as if they might have been formed by hurricanes and blown sand, but we discovered the same rock in the immediate vicinity overlying a basalt, zo feet above the water. The present islets probably represent the remains of a considerable island, elevated for at least roo feet, extending along that part of the barrier reef.

Leaving Mauritius on August 2I, we had three days' dredging and sounding off its reefs. The contour is the same as that off atoll-reefs, a gradual slope to $40 \mathrm{fms}$. (fathoms), succeeded by a steep to $150 \mathrm{fms}$., then tailing off in five miles to $1000 \mathrm{fms}$. The bottom at $150 \mathrm{fms}$. was covered by heavy blocks of coral from the reef above. At $300 \mathrm{fms}$. we found shell and small pieces of coral, and further out a bottom of bare coral mud, sweepings from the reef and 